\title{
The Role of Metabotropic Glutamate Receptor 1 Dependent Signaling in Glioma Viability ${ }^{\mathbb{S}}$
}

\author{
(1) Carrie Bowman Dalley, Barbara Wroblewska, Barry B. Wolfe, and Jarda T. Wroblewski ${ }^{1}$ \\ The Wroblewski Laboratory, Department of Pharmacology and Physiology (C.B.D., B.W., B.B.W., J.T.W.) and School of Nursing \\ and Health Studies (C.B.D.), Georgetown University Medical Center, Washington, District of Columbia
}

Received April 25, 2018; accepted July 18, 2018

\begin{abstract}
Glioma refers to malignant central nervous system tumors that have histologic characteristics in common with glial cells. The most prevalent type, glioblastoma multiforme, is associated with a poor prognosis and few treatment options. On the basis of reports of aberrant expression of mGluR1 mRNA in glioma, evidence that melanoma growth is directly influenced by glutamate metabotropic receptor 1 (mGluR1), and characterization of $\beta$-arrestin-dependent prosurvival signaling by this receptor, this study investigated the hypothesis that glioma cell lines aberrantly express mGluR1 and depend on mGluR1mediated signaling to maintain viability and proliferation. Three glioma cell lines (Hs683, A172, and U87) were tested to confirm mGluR1 mRNA expression and the dependence of glioma cell viability on glutamate. Pharmacologic and genetic evidence is presented that suggests mGluR1 signaling
\end{abstract}

specifically supports glioma proliferation and viability. For example, selective noncompetitive antagonists of mGluR1, CPCCOEt and JNJ16259685, decreased the viability of these cells in a dose-dependent manner, and glutamate metabotropic receptor 1 gene silencing significantly reduced glioma cell proliferation. Also, results of an anchorage-independent growth assay suggested that noncompetitive antagonism of mGluR1 may decrease the tumorigenic potential of Hs683 glioma cells. Finally, data are provided that support the hypothesis that a $\beta$-arrestin-dependent signaling cascade may be involved in glutamate-stimulated viability in glioma cells and that ligand bias may exist at mGluR1 expressed in these cells. Taken together, the results strongly suggest that mGluR1 may act as a proto-oncogene in glioma and be a viable drug target in glioma treatment.

\section{Introduction}

Gliomas are malignant central nervous system tumors that have histologic characteristics in common with glial cells. Astrocytomas account for $80 \%$ of malignant brain tumors, followed by oligodendroglioma, oligoastrocytoma, and ependymal tumors (Ostrom et al., 2014; Robert and Sontheimer, 2014). The World Health Organization grades gliomas (I-IV) on the basis of malignant characteristics, such as the degree of atypical morphology, mitotic activity, vascularization, and necrotic area (Louis et al., 2007). Glioblastoma multiforme (GBM), a grade IV astrocytoma, is the most common form of glioma, with approximately 10,000 patients diagnosed each

${ }^{1}$ Jarda T. Wroblewski, PhD, died before submission of this paper. He was actively involved in experimental design and data analysis prior to his death.

This work was supported by the American Association of Nurse Anesthetists Foundation Doctoral Fellowship, a pilot grant from the Georgetown University Medical Center Dean of Research, Georgetown University Department of Pharmacology and Physiology and Georgetown University School of Nursing and Health Studies.

https://doi.org/10.1124/jpet.118.250159.

S This article has supplemental material available at jpet.aspetjournals.org. year in the United States (Zinn et al., 2013). The current standard of care for GBM involves radiation therapy, surgical resection, and temozolomide (Lacroix et al., 2001; Stupp et al., 2009; Gilbert et al., 2014). However, even with these treatments, GBM survival rates are reported to be only 12-16 months following diagnosis (Robert and Sontheimer, 2014; Roth and Weller, 2014), and GBMs account for the highest number of years of life lost among malignant tumors (Schwartzbaum et al., 2006). Therefore, there is an urgent need to identify more effective pharmacological targets.

One of the largest obstacles in achieving this goal has been the rapid development of resistance to various glioma treatments. For example, it appears that when a single component of a tumorigenic signaling pathway (e.g., epidermal growth factor receptor or vascular endothelial growth factor) is pharmacologically inhibited or targeted with an immunotherapy strategy, compensatory responses occur within that signaling axis to sustain tumor viability and/or inhibition confers a selective advantage to cell populations capable of maintaining viability through alternative cell signaling pathways (Soda et al., 2013; Roth and Weller, 2014; Malkki, 2016).

ABBREVIATIONS: ANOVA, analysis of variance; cDNA, complementary DNA; CHO, Chinese hamster ovary; CPCCOEt, 7-hydroxyiminocyclopropan [b]chromen-1a-carboxylic acid ethyl ester; DHPG, 3,5-dihydroxyphenylglycine; DMEM, Dulbecco's modified Eagle's medium; DMSO, dimethyl sulfoxide; ERK, extracellular signal-regulated kinase; GAPDH, glyceraldehyde 3-phosphate dehydrogenase; GBM, glioblastoma multiforme; GPT, glutamate pyruvate transaminase; GRM1, glutamate metabotropic receptor 1 gene; JNJ16259685, (3,4-dihydro-2H-pyrano[2,3]b quinolin-7-yl) (cis4-methoxycyclohexyl)-methanone; mGluR, metabotropic glutamate receptor; MPEP, 2-methyl-6-(phenylethynyl)pyridine; MTT, 3-[4,5-dimethylthiazol2-yl]-2,5-diphenyltetrazolium bromide; PBS, phosphate-buffered saline; PI, phosphoinositide; shRNA, small/short hairpin RNA; siRNA, small/short inhibitory RNA. 
Thus, it is likely GBM treatment may require concurrent therapies targeting relatively independent mechanisms of tumor proliferation, survival, and migration.

Glutamate is considered the primary excitatory neurotransmitter in the brain and an important mediator of proliferation, migration, and survival during neuronal development (Rzeski et al., 2001). The typical extracellular glutamate concentration in the brain is 1-3 $\mu \mathrm{M}$ (de Groot and Sontheimer, 2011). However, following synaptic glutamate release, glutamate concentrations are estimated to reach $1 \mathrm{mM}$ at the synapse and up to $190 \mu \mathrm{M}$ in perisynaptic regions (Dzubay and Jahr, 1999). Glioma cells in vitro and GBM tumors in vivo have been reported to release high concentrations of glutamate (Robert and Sontheimer, 2014). This finding is attributed to inhibition of reuptake owing to downregulation of sodium- and potassium-dependent excitatory amino acid transporters (EAAT1/2) expression and overexpression of system $x_{c}^{-}$leading to increased glutamate secretion into the extracellular space (Robert and Sontheimer, 2014; Thomas et al., 2015). Gliomas have a distinct survival advantage in this environment; neuronal glutamate receptors become chronically overstimulated, resulting in excitotoxicity and neuronal death, whereas glioma cells thrive in high concentrations of glutamate (Ye and Sontheimer, 1999; de Groot and Sontheimer, 2011). Furthermore, the death of neurons provides space for glioma tumor growth within the constrained cranial compartment (Robert and Sontheimer, 2014).

Group I metabotropic glutamate receptors (mGluR) 1 and 5 have been associated with several types of cancer (Willard and Koochekpour, 2013). For example, aberrant expression of mGluR1 in breast cancer increased malignant characteristics, including proliferation, anchorage-independent growth, and invasiveness (Speyer et al., 2012; Banda et al., 2014). Furthermore, studies in our laboratory (Gelb et al., 2014, 2015a,b) and others (Marín et al., 2006; Namkoong et al., 2007; Shin et al., 2008) have demonstrated that mGluR1 functions as a proto-oncogene in melanoma. However, compared with ionotropic and group II metabotropic glutamate receptors, mGluR1 has received little attention in glioma research. Several independent studies suggest that mGluR1 is expressed in malignant glioma (Parsons et al., 2008; Stepulak et al., 2009; Brocke et al., 2010). However, mGluR1 mRNA or protein has not been detected in normal brain astrocytes (Aronica et al., 2003; D'Antoni et al., 2008) or mature oligodendrocytes (D'Antoni et al., 2008). This observation is particularly interesting when one considers the probable role of mGluR1 in driving tumor growth in malignant melanoma and triple-negative breast carcinoma. For example, mGluR1 complementary DNA (cDNA) cloned into melanocytes and then allografted into a mouse model results in the formation of invasive, highly vascularized tumors (Shin et al., 2008). This tumorigenic phenotype was significantly reduced with small/short inhibitory (si)RNA treatment, indicating that mGluR1 expression was critical for maintenance of the malignant transformation (Shin et al., 2008).

Our laboratory has reported a mechanism by which glutamate-stimulated mGluR1 mediates cell survival and proliferation. This mechanism involves ligand bias and a $\mathrm{G} \alpha_{\mathrm{q}}$-independent, $\beta$-arrestin-dependent signaling cascade that induces sustained extracellular signal-regulated kinase (ERK) phosphorylation and subsequent improved viability in serum-deprived cell cultures (Emery et al., 2010). These effects have been confirmed in Chinese hamster ovary (CHO) cells stably expressing mGluR1 (Emery et al., 2012), and have been supported by results in cerebellar granule neurons (Hathaway et al., 2015), and in mGluR1-positive melanoma cell lines (Gelb et al., 2015a). Our laboratory's findings indicate that this prosurvival signaling pathway may be active in a variety of mGluR1-expressing cell types and may reveal the receptor to be a novel drug target against multiple types of malignant growth, including glioma.

Therefore, on the basis of reports of aberrant expression of mGluR1 mRNA in glioma, accumulating evidence that melanoma growth is directly influenced by mGluR1 signaling, and characterization of $\beta$-arrestin-dependent prosurvival signaling by this receptor, we investigated the possibility that mGluR1 influences the proliferation and survival of three commonly used glioma cell lines. The Hs683 cell line was selected as a model for a highly infiltrative oligodendroglioma, and the U87 and A172 cell lines served as models for GBM (Giard et al., 1973; Camby et al., 2000; Maglott et al., 2006; Le Mercier et al., 2009; Duffau, 2013).

\section{Materials and Methods}

Materials. Glioma cell lines (H4, Hs683, U87, A172, and U118) were provided by the Lombardi Comprehensive Cancer Center Tissue Culture Shared Resource at Georgetown University (Washington, DC). Dulbecco's modified Eagle's medium (DMEM), antibioticantimycotic, amphotericin B (Fungizone), fetal bovine serum, dialyzed fetal bovine serum, Amplex Red Glutamic Acid/Glutamate Oxidase Assay Kit, and MTT (thiazolyl blue tetrazolium) were purchased from Life Technologies/Thermo Fisher Scientific (Carlsbad, CA). CyQUANT cell proliferation assay kit and Lipofectamine 3000 Reagent was purchased from Thermo Fisher Scientific (Grand Island, NY). Glutamate pyruvate transaminase (GPT) was purchased from Roche (Indianapolis, IN). Calcein AM was purchased from MilliporeSigma (St. Louis, MO). Glutamate, aspartate, quisqualate, CPCCOEt, JNJ16259685, dynasore (PubChem CID:5717066), and MPEP were purchased from Tocris Bioscience (Bristol, United Kingdom).

Cell Culture. All glioma cell lines were cultured in DMEM media supplemented with penicillin (100 IU/ml), streptomycin $(100 \mu \mathrm{g} / \mathrm{ml})$, amphotericin B $(2.5 \mu \mathrm{g} / \mathrm{ml})$, and either $10 \%$ fetal bovine serum (full media) or $10 \%$ dialyzed fetal bovine serum (dialyzed media). Dialyzed fetal bovine serum was treated by the manufacturer to remove all small molecules (mol. wt. $<10,000$ ), including glutamate. Full media was prepared using DMEM that contained $4 \mathrm{mM}$ L-glutamine, and dialyzed media was prepared with L-glutamine-free DMEM. The cells were grown at $37^{\circ} \mathrm{C}$ and $5 \% \mathrm{CO}_{2}$. $\mathrm{CHO}$ cells were cultured under the same conditions with proline supplementation $(4.5 \mathrm{~g} / 500 \mathrm{ml})$ of the media.

Viability Assays (MTT and Calcein AM). Cells were plated in $100 \mu \mathrm{l}$ of full media on a 96-well plate: 7000 cells per well for U87 cells and 9000 cells per well for Hs683 and A172 cells. The following day, the drugs were added. Five days later, the ability of the cells to metabolize MTT (thiazolyl blue tetrazolium) (Life Technologies) was measured according to manufacturer's instructions on an EnVision plate reader (PerkinElmer, Waltham, MA). For calcein AM determination, the cells were incubated as above. Five days after drug application, calcein AM was added. After a 30-minute incubation period at $37^{\circ} \mathrm{C}$, fluorescence was quantified on the plate reader with an excitation wavelength of $485 \mathrm{~nm}$ and an emission wavelength of $530 \mathrm{~nm}$.

Measurement of Glutamate Concentration. The concentration of glutamate released by the cells was measured using the Amplex Red Glutamic Acid/Glutamate Oxidase Assay Kit (Life Technologies) 
without the amplification step. U87 (7000 cells/well) and A172 and Hs683 (each 9000 cells/well) cells were plated on 96-well plates in $100 \mu \mathrm{l}$ of full media. Twenty-four hours later, the cells were washed with phosphate-buffered saline twice and $100 \mu \mathrm{l}$ per well of media containing dialyzed serum (lacking glutamate) was applied. The media was collected on days 1,3 , and 5 following the media change, and the glutamate concentration was quantified by Amplex Red fluorescence as measured at an excitation wavelength of $570 \mathrm{~nm}$ and an emission wavelength of $585 \mathrm{~nm}$. The values obtained were then fit to a standard glutamate concentration curve (Supplemental Fig. 1).

Glutamate Pyruvate Transaminase. Unless otherwise indicated, GPT was applied to cell cultures at a concentration of $35 \mu \mathrm{g} / \mathrm{ml}$ with $10 \mathrm{mM}$ pyruvate, 24 hours after plating. After a 5-day incubation period, an MTT assay was used (as above) to quantify the GPT effect.

Detection of mGluR1 mRNA. Total RNA was extracted from glioma cells cultured on 60-mm dishes using the NucleoSpin RNA Plus protocol (Macherey-Nagel, Bethlehem, PA) according to the manufacturer's instructions. Extracted RNA was measured using a nanophotometer (Implen GmbH, Munich, Germany). Equal concentrations of RNA were reverse-transcribed to cDNA using Life Technologies High Capacity cDNA Reverse Transcription Kit and protocol. Next, reverse transcription-polymerase chain reaction (RT-PCR) was performed to detect mGluR1 expression in the various samples using the Phusion High-Fidelity DNA Polymerase Kit and protocol (New England Biolabs, Ipswich, MA). mGluR1 primers were designed to detect mGluR1a (amplicon $650 \mathrm{bp}$ ) and mGluR1b (amplicon $735 \mathrm{bp}$ ) as described previously (DiRaddo et al., 2013). Briefly, the mGluR1 primer sequences used spanned exons VIII-X of the glutamate metabotropic receptor 1 gene (GRM1). The difference in amplicon size between the splice variants is expected because mGluR1b contains an 85-bp exon (IXC) between exons VIII and X that is absent in mGluR1a mRNA. The primer sequences used were forward 2661 ATGCCCATTCTGTCCTACCCAAGT and reverse 3286 GCTCTGGCAAGAGCCTGACCTTTTC. A CHO cell line stably expressing human mGluR1a was used as a positive control. GAPDH detection was used as an internal standard.

mGluR1 SmallShort Hairpin RNA Transfections. Five psi-U6 plasmids containing the enhanced green fluorescent protein reporter gene and a puromycin resistance gene were purchased from GeneCopoeia (Rockville, MD). One plasmid served as a scrambled small/short hairpin (sh)RNA control (cat. no. CSHCTR001-CU6), whereas the other four contained shRNA sequences targeting GRM1 as follows: (starting base listed) 722 (cacgttggataagatcaac), 1507 (aggtcaggtcatttgatga), 1978 (gagtgctgaacattgatga), and 2690 (ggaagtctaccttatctgc) [cat. no. HSH008436-(1-4)-CU6]. Glioma cells were plated to achieve approximately $80 \%$ confluency on 60 -mm dishes and incubated overnight at $37^{\circ} \mathrm{C}$ and $5 \% \mathrm{CO}_{2}$. The following day, cells were transfected with either a combination of the four plasmids targeting mGluR1 mRNA (total $5 \mu \mathrm{g}$ cDNA), the plasmid containing scrambled shRNA (5 $\mu \mathrm{g}$ cDNA), or treated with transfection agent only (vehicle). Lipofectamine 3000 reagent was used following the manufacturer suggested siRNA transfection protocol.

Proliferation Assay (CyQUANT Cell Proliferation Kit). One day after transfection with mGluR1 shRNA plasmids, control scrambled-shRNA plasmid, or vehicle, cells were plated on 96-well plates at 6500 cells/well and incubated at $37^{\circ} \mathrm{C}$ and $5 \% \mathrm{CO}_{2}$. The samples were collected at 24,48 , and 72 hours after plating, treated according to the manufacturer's suggestion, and fluorescence was quantified on a microplate reader with an excitation wavelength of $485 \mathrm{~nm}$ and emission wavelength of $520 \mathrm{~nm}$. A standard curve using a serial dilution of Hs683 glioma cells confirmed that cell densities were in the linear range of detection (Supplemental Fig. 2).

Anchorage-Independent Growth. Anchorage-independent growth was measured using the soft agar colony formation assay described by Borowicz et al. (2014). In brief, $1.5 \mathrm{ml}$ of $0.5 \%$ Noble agar in DMEM media containing either 1\% dimethyl sulfoxide (DMSO), or 30,100 , or $300 \mu \mathrm{M}$ JNJ16259685 in 1\% DMSO was plated onto a sixwell plate to form a bottom layer. After allowing 30 minutes at room temperature for bottom layer solidification, 10,000 Hs683 cells per well were plated in $1.5 \mathrm{ml}$ of $0.3 \%$ Noble agar in DMEM media in either $1 \%$ DMSO, or 30,100 , or $300 \mu \mathrm{M}$ JNJ16259685 in 1\% DMSO over the bottom layer of agar with matching treatment conditions. Following an additional 30 minutes at room temperature, the plates were moved to an incubator set at $37^{\circ} \mathrm{C}$ and $5 \% \mathrm{CO}_{2}$. Twice per week, $100 \mu \mathrm{l}$ of DMEM and the respective treatment (DMSO only, 30, 100, or $300 \mu \mathrm{M}$ JNJ16259685) were added to the wells to replace evaporative losses. After 21 days, $200 \mu \mathrm{l}$ of nitro blue tetrazolium chloride was applied to each well to stain the colonies present and the plates were placed back in the incubator overnight. The following day, the plates were photographed and analyzed using Image J, which generated values for colony number and colony area on the basis of detection of blue color. Average colony size was calculated using: (sum of colony area per well)/(number of colonies per well). A grand mean for each experiment was calculated and used to normalize the data within each individual experiment. A total of three $(100 \mu \mathrm{M})$ or four independent experiments [DMSO, 30, $300 \mu \mathrm{M}$ JNJ16259685 (JNJ)] were conducted, each measured in duplicate. For the final presentation, the means from the independent experiments were averaged and normalized to the mean of the control group (DMSO).

Statistical Analysis. Prism 7.0 (GraphPad Software, San Diego, CA) was used to model nonlinear regression using the variable slope, four-parameter equation. One-way analysis of variance (ANOVA) using Dunnett's multiple comparisons test or when multiple groups were compared Tukey's multiple comparisons test was used.

\section{Results}

The Continuous Presence of Glutamate Promotes Glioma Cell Line Viability. To evaluate the effects of glutamate on glioma cell line viability, exogenous glutamate was added to the growth media. Glioma cell lines (Hs683, A172, and U87) were incubated in standard media conditions (media and serum containing glutamate; termed: full media), media with dialyzed serum (termed: dialyzed media), and media with dialyzed serum supplemented with increasing concentrations of glutamate (Fig. 1A). Following a 5-day incubation period, cellular viability was measured using the MTT assay. As shown in Fig. 1A, Hs683 glioma cell line viability dose dependently increased in the presence of glutamate $\left[\mathrm{EC}_{50} 3.7 \mathrm{mM}(95 \% \mathrm{CI}: 2.3-6.0)\right.$ ]. This value was consistent with the $\mathrm{EC}_{50}$ of glutamate reported to promote viability in melanoma cell lines known to aberrantly express mGluR1, such as SK-MEL-2 $\left(\right.$ EC $\left._{50}=4.3 \mathrm{mM}\right)$, and SK-MEK-5 $\left(\mathrm{EC}_{50} 3.4 \mathrm{mM}\right.$ ) (Gelb et al., 2015b). Furthermore, the cytoprotective effect of glutamate was observed in all glioma cell lines tested. When incubated in dialyzed media, Hs683, A172, and U87 cell line viabilities were reduced to $37 \%( \pm 4), 45 \%( \pm 7)$, and $48 \%( \pm 11)$ of full media controls, respectively (Fig. 1D). However, when dialyzed media was supplemented with $20 \mathrm{mM}$ glutamate, viabilities returned to $79 \%( \pm 13), 93 \%$ $( \pm 18)$, and $90 \%( \pm 7)$ of full media controls in Hs683, A172, and U87 cell lines, respectively (Fig. 1D).

Recent reports indicate that the MTT assay may have offtarget effects leading to inaccurate measurements of cellular viability under some treatment conditions (Jo et al., 2015; Stepanenko and Dmitrenko, 2015). Therefore, we confirmed our results in two alternative cellular viability assays that are not directly influenced by mitochondrial function; the calcein $\mathrm{AM}$ assay, which measures esterase activity in intact (live) cells, and the CyQUANT cell proliferation assay, which measures nucleic acid content (an indirect measure of cell number). When A172 cells were incubated for 5 days under 
A

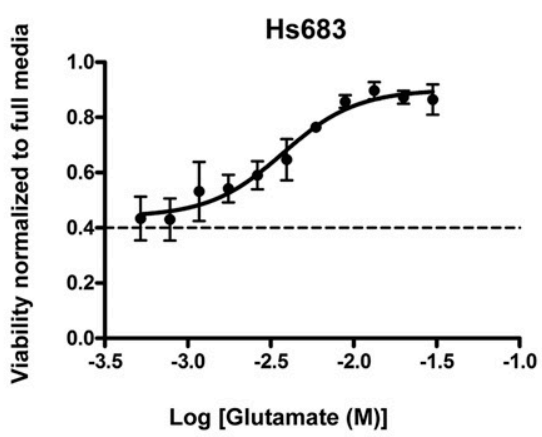

D

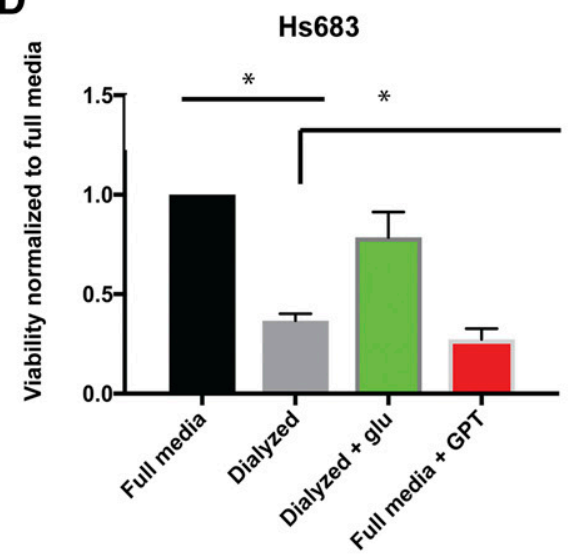

B

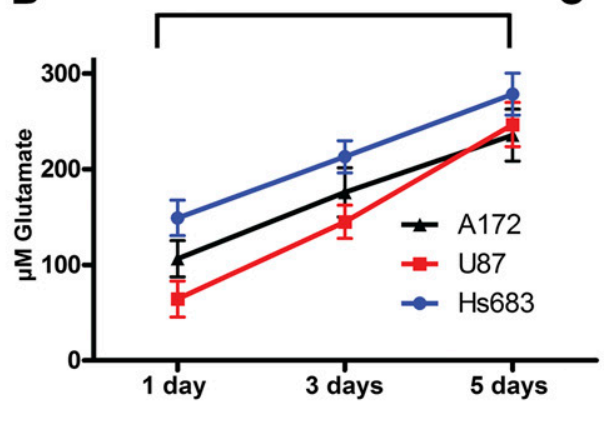

A172

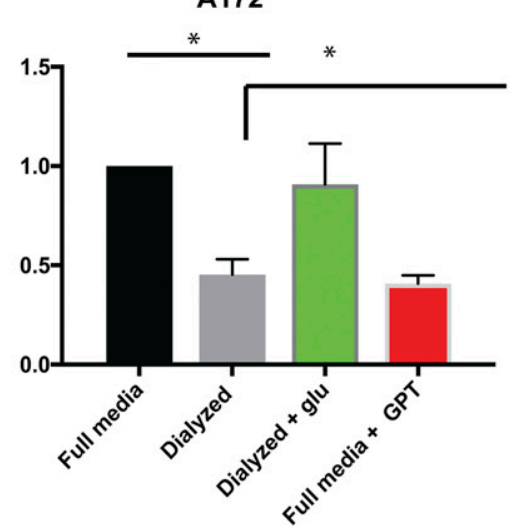

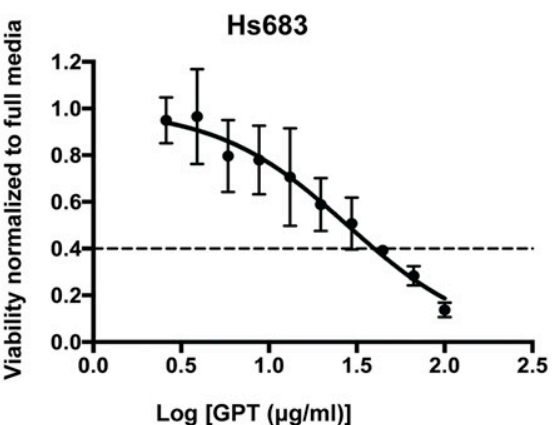

$\log [\mathrm{GPT}(\mu \mathrm{g} / \mathrm{ml})]$

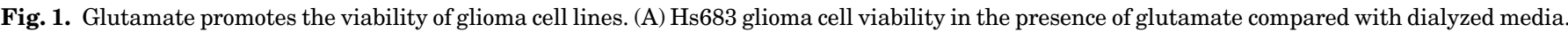

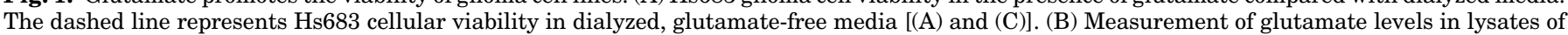

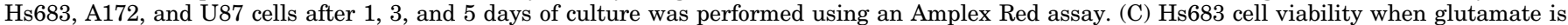

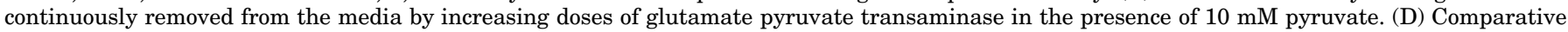

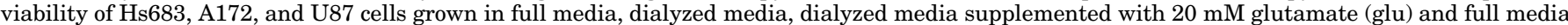

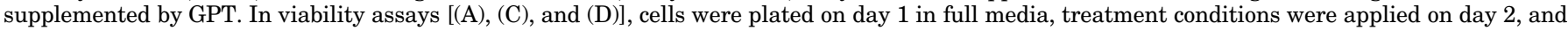

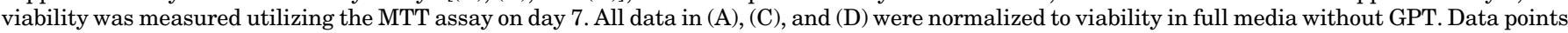

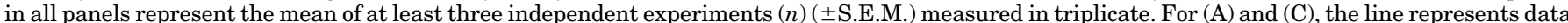

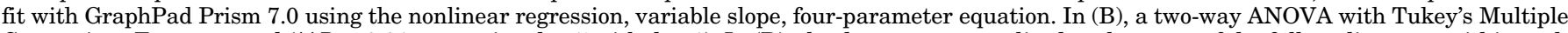

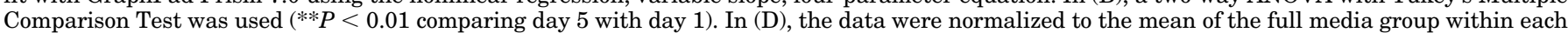

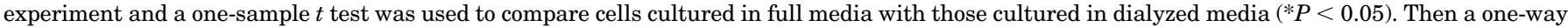
ANOVA with Dunnett's Multiple Comparisons Test was used to compare the dialyzed group to the treatment groups (*P $<0.05$ ).

treatment conditions, calcein AM and MTT assays provided comparable results when the effect of glutamate supplementation on cellular viability was measured (Supplemental Fig. 3, A and C). Likewise, when Hs683 viability was measured using the CyQUANT assay (after 3 days of treatment), the results were analogous to viability measured by the MTT assay (after 5 days of treatment) (Supplemental Fig. 3, B and D). Therefore, it appeared MTT was providing an accurate assessment of glioma cell viability in this model.

The release of glutamate by glioma cells is well documented in the literature (Ye and Sontheimer, 1999; Takano et al., 2001; Lyons et al., 2007; Buckingham et al., 2011). We confirmed this finding and quantified the release of glutamate by cell lines used in this study (Fig. 1B). Glutamate concentrations measured 5 days after plating in dialyzed media were $278 \mu \mathrm{M}( \pm 22), 235 \mu \mathrm{M}( \pm 27)$, and $246 \mu \mathrm{M}( \pm 23)$ in Hs683, A172, and U87 cells, respectively, as measured by the Amplex Red assay. Concentrations within this range have been shown to promote survival in cells known to express high levels of mGluR1 protein, such as CHO cells heterologously expressing mGluR1 $\left(\mathrm{EC}_{50}=153 \mu \mathrm{M}\right)$ and cerebellar granule neurons
$\left(\mathrm{EC}_{50}=76 \mu \mathrm{M}\right)$ (Emery et al., 2010; Hathaway et al., 2015). Therefore, it is probable that glutamate released over a 5-day incubation period could partially rescue glioma cells cultured in dialyzed media, decreasing the sensitivity of the data in Fig. 1A.

To address this confounding factor, glutamate pyruvate transferase was added to full media to enzymatically remove glutamate as it was released (Fig. 1, C and D). GPT removes glutamate by catalyzing the conversion of glutamate and pyruvate to $\alpha$-ketoglutarate and alanine, respectively. In the presence of GPT, Hs683 viability was dose dependently reduced [IC $\mathrm{IC}_{50} 28 \mu \mathrm{g} / \mathrm{ml}$; CI 95\% (4-181)] (Fig. 1C). The dependence on glutamate, as revealed by GPT, was observed in all cell lines tested. Viability was reduced to $27 \%( \pm 5), 41 \%$ $( \pm 4)$, and $34 \%( \pm 4)$ of full serum controls in Hs683, A172, and U87 cell lines, respectively (Fig. 1D). As expected, in cells treated with high concentrations of GPT, viability was lower compared with cells cultured in dialyzed media only (Fig. 1C). Presumably, this enhanced viability in dialyzed media reflects an autocrine effect of the glutamate released from the glioma cells over the 5-day incubation period. This effect was 
prevented in GPT-containing wells where the released glutamate was enzymatically cleared from the media upon release. Taken together, these results indicate that glioma cell lines are dependent on glutamate for sustained viability.

mRNA Encoding mGluR1 Was Confirmed in Five Human Glioma Cell Lines by RT-PCR. Using RT-PCR, we tested the expression of native mGluR $1 \mathrm{mRNA}$ in multiple glioma cell lines. Primers designed to detect mGluR1a and mGluR1b mRNA transcripts amplified two distinct bands at the appropriate base-pair weights in H4 (low-grade glioma), Hs683 (oligodendroglioma), U87 (GBM/astrocytoma), A172 (GBM/astrocytoma), and U118 (GBM/astrocytoma) cell lines (Fig. 2). The expression level varied among the cell lines. For example, H4 cells produced an mGluR1a band just above the threshold of detection, whereas robust mGluR1a signals were observed in the other cell lines (Fig. 2). However, the band intensity of the loading control, GAPDH, was consistent, indicating equal starting concentrations of cDNA. These results suggest that the mGluR1 gene, GRM1, is actively transcribed in human-derived glioma cells and that the receptor transcription level varies among the various glioma cell lines. It would have been ideal to have confirmed also the expression of mGluR1 protein; unfortunately, we found that all currently available commercial mGluR1 antibodies lacked specificity for human mGluR1. Therefore, we were not able to successfully complete these experiments. Should an effective human mGluR1 antibody become available, it would be important to confirm protein expression.

$\beta$-Arrestin-Dependent mGluR1 Signaling May Contribute to Glioma Cell Line Viability. Studies conducted in our laboratory have suggested a positive impact of mGluR1dependent signaling on cellular viability in several models, including $\mathrm{CHO}$ cells heterologously expressing mGluR1, cerebellar granule neurons, and melanoma cell lines (Emery et al., 2010; Gelb et al., 2015a; Hathaway et al., 2015). In addition, these studies have consistently concluded that ligand bias exists at mGluR1 and that: 1) unbiased ligands, such as glutamate and aspartate, can activate either the canonical $\mathrm{G} \alpha_{\mathrm{q}}$ pathway or a $\beta$-arrestin-dependent pathway that increases cellular viability, and 2) biased ligands such as quisqualate and DHPG can only activate the $\mathrm{G} \alpha$ q pathway and do not have a positive impact on cellular viability (Emery et al., 2010, 2012; Gelb et al., 2015a; Hathaway et al., 2015). Therefore, we tested if mGluR1 signaling in glioma followed a similar pattern. Hs683 cells were cultured in full media (viability $=100 \%$ ), dialyzed media [viability $=36 \%( \pm 2)$ ], or dialyzed media in the presence of various mGluR1 agonists for 5 days and then subjected to the MTT assay (Fig. 3A). As expected, $20 \mathrm{mM}$ glutamate acted as a full agonist in dialyzed media with viability measured at $84 \%( \pm 5)$ of full serum controls. Aspartic acid was a less potent or efficacious agonist in dialyzed media with a viability $67 \%( \pm 3)$ of full serum controls. However, G $\alpha$ q-biased agonists DHPG and quisqualate did not significantly promote $\mathrm{Hs} 683$ cell line viability even when used in concentrations 100- and 300-fold higher than their reported $\mathrm{EC}_{50}$ values, respectively $\left(\mathrm{DHPG} \mathrm{EC}_{50}=10 \mu \mathrm{M}\right.$ and quisqualate $\mathrm{EC}_{50}=1 \mu \mathrm{M}$ ) (Emery et al., 2012). For example, $1 \mathrm{mM}$ DHPG-treated cells had a viability of $31 \%( \pm 2)$ and $300 \mu \mathrm{M}$ quisqualate-treated cells had a viability of $38 \%$ ( \pm 6$)$ compared with full serum controls (Fig. 3A). Like results were obtained using A172 and U87 cell lines (Supplemental Fig. 4). Below, we present pharmacologic and genetic evidence indicating that mGluR1 specifically mediates glioma cell viability. In this context, these agonist viability results suggest that ligand bias may also occur at mGluR1 expressed on glioma cells.

To further investigate the possibility that $\beta$-arrestindependent signaling was contributing to the effect of glutamate on glioma cell viability, the effects of dynasore on viability were measured. Dynasore inhibits the GTPase activity of dynamin, a critical player in clathrin-mediated endocytosis, which is a prerequisite step in $\beta$-arrestindependent signaling (Macia et al., 2006). We found that dynasore dose dependently blocked the positive effect of glutamate on glioma cell line viability in Hs683 cells with an $\mathrm{IC}_{50}$ of $31.8 \mu \mathrm{M}$ [CI 95\% (24.1-42.1)] (Fig. 3B). In contrast, when increasing concentrations of dynasore were added to the cells grown in dialyzed media (with no supplemental glutamate and GPT added to enzymatically remove secreted glutamate), the data could not be fit to a curve. This finding suggests dynasore's effect was associated with blockade of a glutamate-mediated effect and not a nonspecific toxicity.
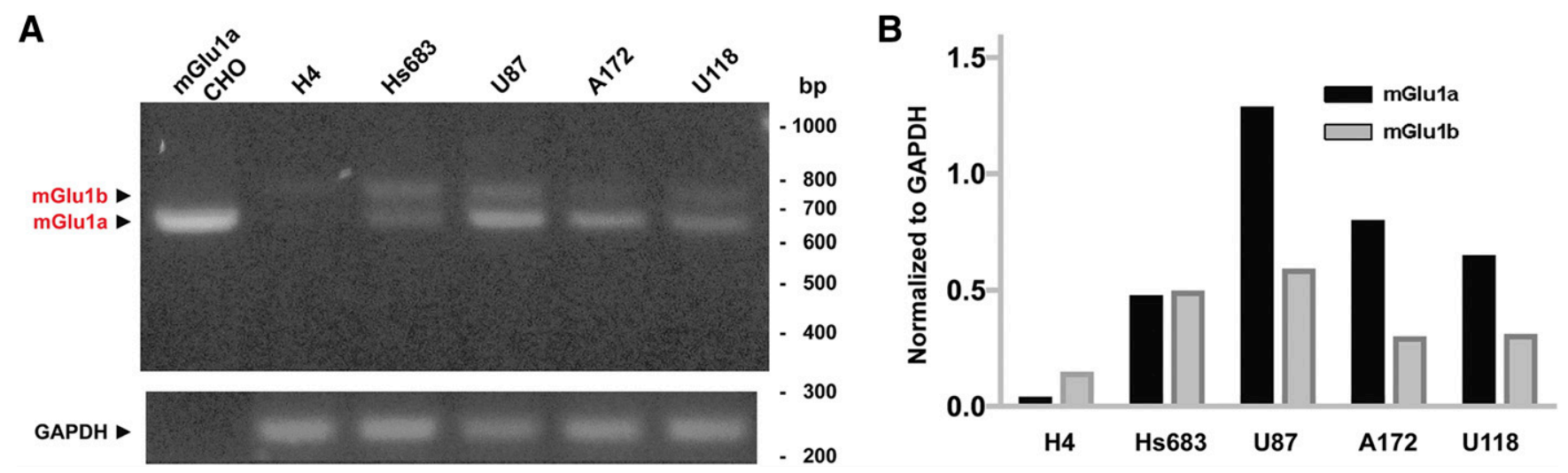

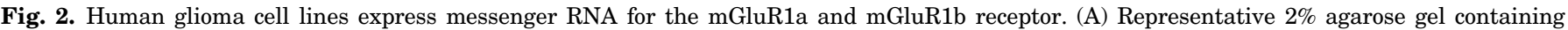

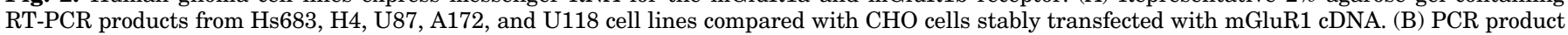

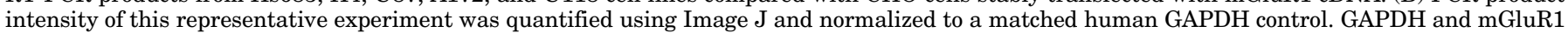
are products of separate reactions that included equivalent volumes of the same aliquot of cDNA. Photographs were cropped to promote clarity. 
A

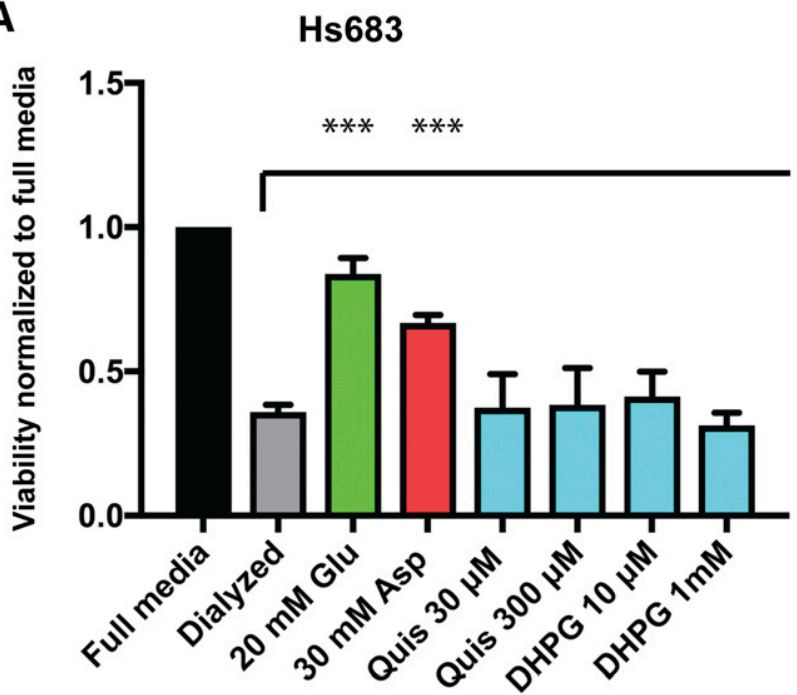

B

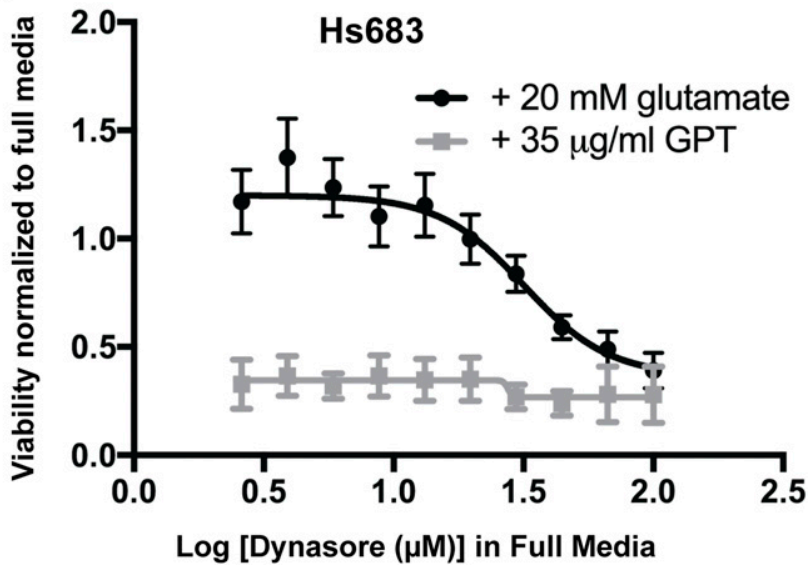

Fig. 3. Glioma cell viability is promoted by unbiased mGlu1 receptor agonists and blocked by the inhibitor of receptor internalization (dynasore). (A) Comparative viability of $\mathrm{Hs} 683$ cells grown in the presence of either full media, dialyzed media, or dialyzed media with glutamate (Glu), aspartate (Asp), DHPG, or quisqualate (Quis). (B) Hs683 cell viability when increasing concentrations of dynasore were added to dialyzed media with either supplemental glutamate or GPT (added to enzymatically remove glioma-secreted glutamate). Cellular viability was measured using the MTT assay and data were normalized to viability in full serum. Each data point represents the mean ( \pm S.E.M.) of at least three independent experiments $(n)$ measured using the MTT assay in triplicate or more. In (A), one-way ANOVA with Dunnett's Multiple Comparisons Test was used to measure the differences between groups $(* * * P<0.001$, compared to viability in dialyzed media). In (B) nonlinear regression was used to fit the data using a variable-slope, four-parameter equation.

In the Presence of Glutamate, Selective Antagonists of mGluR1 Negatively Impact the Viability of Glioma Cell Lines in a Dose-Dependent Manner. After confirming active transcription of the mGluR1 gene in multiple glioma cell lines and the dependence of glioma cell line viability on nonbiased mGluR1 agonists such as glutamate and aspartate, we then examined the effect of mGluR1 antagonists in this model. Hs683 cells cultured in full media and treated with increasing concentrations of the noncompetitive mGluR1 antagonist JNJ demonstrated reduced viability, with an $\mathrm{IC}_{50}$ of $192 \mu \mathrm{M}$ [CI 95\% (138-266)] (Fig. 4A). Likewise, when Hs683 cells were grown in dialyzed media supplemented with $20 \mathrm{mM}$ glutamate, increasing concentrations of JNJ reduced viability with an $\mathrm{IC}_{50}$ of $182 \mu \mathrm{M}$ [CI 95\% (152-218)] (Fig. 4B). These $\mathrm{IC}_{50}$ values were higher than the widely reported $\mathrm{IC}_{50}$ for inhibition of $\mathrm{G} \alpha_{\mathrm{q}}$ signaling as measured by phosphoinositide (PI) hydrolysis (0.5 nM) (Lavreysen et al., 2004) but were similar to the reported $\mathrm{IC}_{50}$ for inhibition of cell viability in mGluR1-positive melanoma cell lines SK-MEL-2 $(109 \mu \mathrm{M})$ and SK-MEK-5 (105 $\mu \mathrm{M})$ (Gelb et al., 2015b) and in cerebellar granule neurons (19.8 $\mu \mathrm{M})$ (Hathaway et al., 2015). A second noncompetitive antagonist, CPCCOEt, also inhibited Hs683 viability when added to dialyzed media containing $20 \mathrm{mM}$ glutamate, with an $\mathrm{IC}_{50}$ of $321 \mu \mathrm{M}$ [CI 95\% (271-381)] (Fig. 4C). Conversely, when increasing concentrations of JNJ (Fig. 4B) or CPCCOEt (Fig. 4C) were applied to the cells in dialyzed media without supplemental glutamate and with GPT added to enzymatically remove secreted glutamate, the data did not fit to a dose-response curve. This suggests the antagonist-mediated reduction in viability was not the result of a nonspecific toxicity and could be attributed to antagonism of mGluR1 signaling.

Our findings were consistent in all glioma cell lines tested. JNJ and CPCCOEt responses were tested at two concentrations in the presence of $20 \mathrm{mM}$ glutamate and dialyzed media (Fig. 4D). In A172 cells, 100 and $300 \mu \mathrm{M}$ JNJ reduced the protective effect of glutamate with viabilities measured at $58 \%$ $( \pm 7)$ and $21 \%( \pm 3)$, respectively, compared with full media controls. Likewise, CPCCOEt at 100 and $350 \mu \mathrm{M}$ reduced the protective effect of glutamate, with viability measured at $46 \%$ $( \pm 14)$ and $22 \%( \pm 5)$ compared with full serum controls. In U87 cells, 100 and $300 \mu \mathrm{M}$ JNJ reduced the protective effect of glutamate with viabilities measured at $80 \%( \pm 6)$ and $17 \%$ $( \pm 2)$ compared with full serum controls. Likewise, CPCCOEt at 100 and $350 \mu \mathrm{M}$ reduced the protective effect of glutamate with viability to $66 \%( \pm 9)$ and $32 \%( \pm 2)$ compared with full serum controls.

Although mGluR1 has not been shown to be expressed in astrocytes (Aronica et al., 2003) or to be functionally relevant to their physiology, the other group I metabotropic receptor, mGluR5, which shares considerable sequence homology with mGluR1, is highly expressed in astrocytes (Loane et al., 2012). mGluR5 has also been shown to be upregulated in astrocytes in pathologic conditions including epilepsy, multiple sclerosis, and amyotrophic lateral sclerosis (Loane et al., 2012). Therefore, it was important to determine if mGlu5 receptor signaling was contributing to glutamate's observed survival benefit in glioma cells. To test this possibility, MPEP, a selective, noncompetitive, mGluR5 antagonist, was applied to Hs683, A172, and U87 cells in concentrations 10- and 1000-fold higher than the $\mathrm{IC}_{50}$ reported for MPEP at mGluR5 (36 nM) (Gasparini et al., 1999). As shown in Supplemental Fig. 5, $300 \mathrm{nM}$ and $30 \mu \mathrm{M}$ MPEP did not significantly block the protective effect of $20 \mathrm{mM}$ glutamate in any cell line tested. Therefore, the group I antagonist data indicate that the protective effect of glutamate is most probably selectively modulated by mGluR1.

mGluR1 shRNA Reduces Glioma Cell Line Proliferation. Having established that selective mGluR1 antagonists decrease glioma viability, we then used a gene silencing approach to confirm our pharmacological data. Four plasmids, each encoding shRNA targeting mGluR1 in a different location, were transfected into Hs683 glioma cells. A plasmid containing a scrambled shRNA was used to assess nonspecific 
A

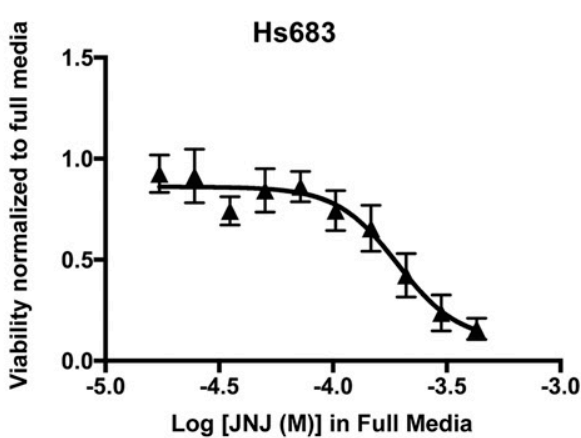

D

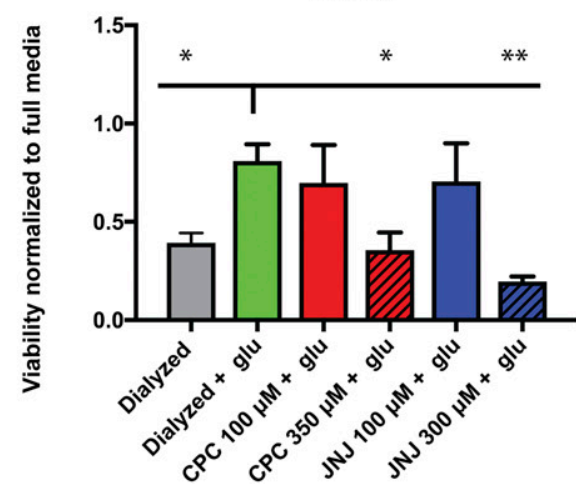

B

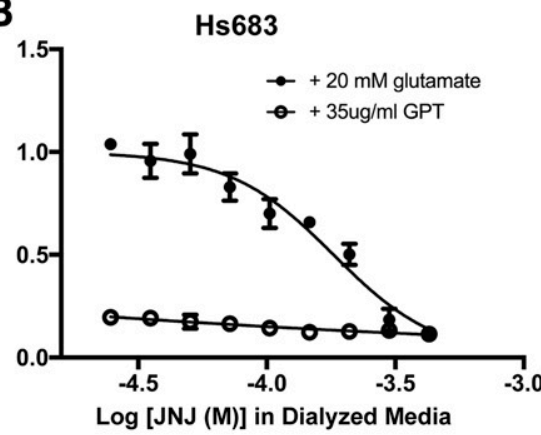

A172

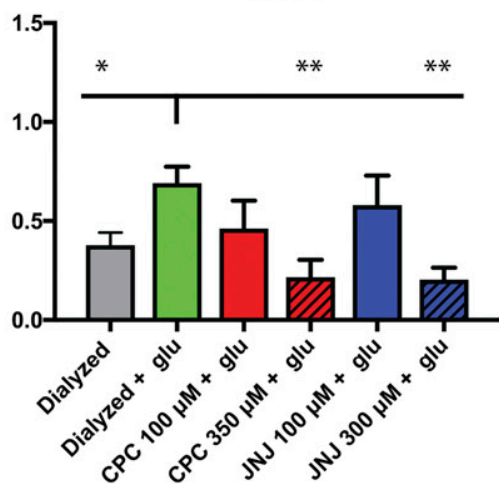

C

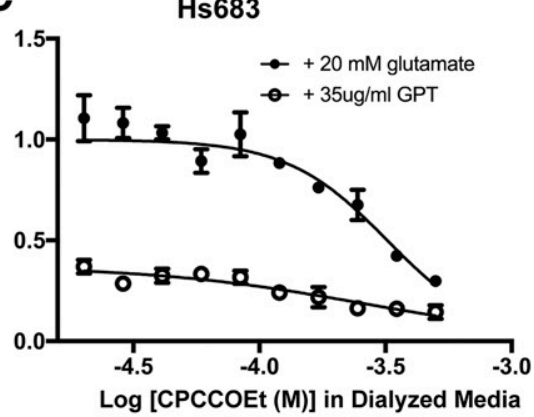

U87

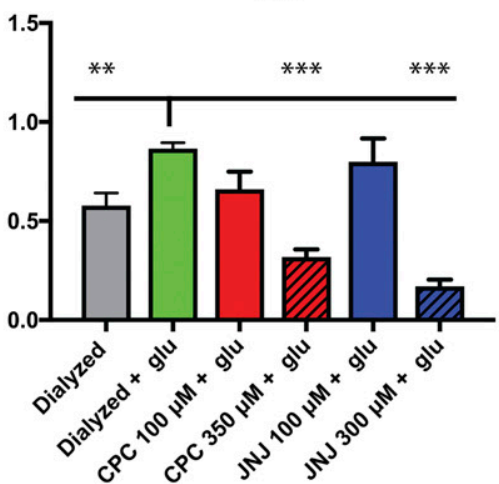

Fig. 4. Selective noncompetitive antagonists of the mGluR1 decrease the viability of Hs683 cells in a dose-dependent manner. Hs683 cells cultured in full media (A) or dialyzed media supplemented with $20 \mathrm{mM}$ glutamate (glu) (B) and treated with increasing concentrations of the noncompetitive mGluR1 antagonists JNJ16259685 (JNJ) or CPCCOEt (CPC). (C) In the experiments utilizing dialyzed media, a control condition was included to which GPT was added to enzymatically remove glioma-secreted glutamate. (D) Comparative viability of Hs683, A172, and U87 cells grown in dialyzed media or dialyzed media supplemented with $20 \mathrm{mM}$ glutamate (glu) and different concentrations of the antagonists. Cellular viability was measured using the MTT assay and data were normalized to viability in full serum. Each data point represents the mean of three independent experiments $(n)( \pm$ S.E.M. $)$ measured in triplicate. The data were analyzed with GraphPad Prism 7.0 using the nonlinear regression, variable-slope, four-parameter equation $[(\mathrm{A})-(\mathrm{C})]$ and one-way ANOVA with Dunnett's Multiple Comparisons Test was used to measure the differences between groups $(\mathrm{D})(* P<0.05$; $* * P<0.01 ; * * * P<0.001$ comparing to viability in dialyzed media $+20 \mathrm{mM}$ glutamate).

plasmid toxicity. Transfection of the plasmid was confirmed by GFP signal, and gene knockdown was evaluated using RT-PCR (Fig. 5A). As expected, mGluR1a and mGluR1b amplicons were detected in Hs683 glioma cells transfected with a scrambled shRNA control plasmid. In contrast, mGluR1a and mGluR1b were effectively silenced in Hs683 glioma cells transfected with four different mGluR1-targeted shRNA plasmids.

Following confirmation of effective mGluR1 knockdown, an attempt to establish a stable cell line was made using increasing concentrations of puromycin, selecting for transfected cells containing the plasmids' puromycin resistance gene. However, despite a robust initial GFP signal, the cells did not survive the selection process, consistent with the hypothesis that mGluR 1 is important for glioma cell viability. Therefore, we shifted to a transient transfection approach. The 5-day incubation period required to optimally detect viability differences using the MTT protocol was not appropriate considering the short duration of transient transfection. Therefore, the CyQUANT cell proliferation assay, which has adequate sensitivity to detect differences 3 days after shRNA transfection was used (Supplemental Fig. 3B).

Measuring the proliferative activity over time in 96-well plates, we found Hs683 cells treated with mGluR1 shRNA had significantly less nucleic acid content per well compared with those treated with a scrambled shRNA control or with transfection agent alone at 72 hours (Fig. 5B). Also, no difference was noted between Hs683 cells exposed to transfection agent only and those transfected with the scrambled shRNA control plasmid at 72 hours, validating the specificity of mGluR1 shRNA effect. These results demonstrate that mGluR1 knockdown specifically reduced the proliferation of glioma cells over time and strongly support the hypothesis that mGluR1 plays a significant role in the proliferative activity and viability of glioma cells in vitro.

The mGluR1 Antagonist JNJ16259685 Dose Dependently Reduced Anchorage-Independent Growth in Hs683 Cells. The ability of cells from cancerous tissues to form colonies in semisolid media is a well established predictor of tumorigenic and metastatic phenotypes in animals (Freedman and Shin, 1974; Mori et al., 2009). Therefore, we tested the ability of Hs683 cells to grow in a soft agar colony formation assay. "Extreme" anchorage-independent growth has been defined as more than 500 colonies in a $35-\mathrm{mm}$ well following a 3-week incubation in soft agar; while "extreme" anchorage-dependent growth has been defined as less than 20 colonies (Mori et al., 2009). When we cultured Hs683 cells under these conditions, the cells exhibited significant anchorageindependent growth with an average colony number of $403( \pm 89)$ per well and average colony size of $29 \mu \mathrm{m}^{2}( \pm 5)$ (Fig. 6). However, when the noncompetitive mGluR1 

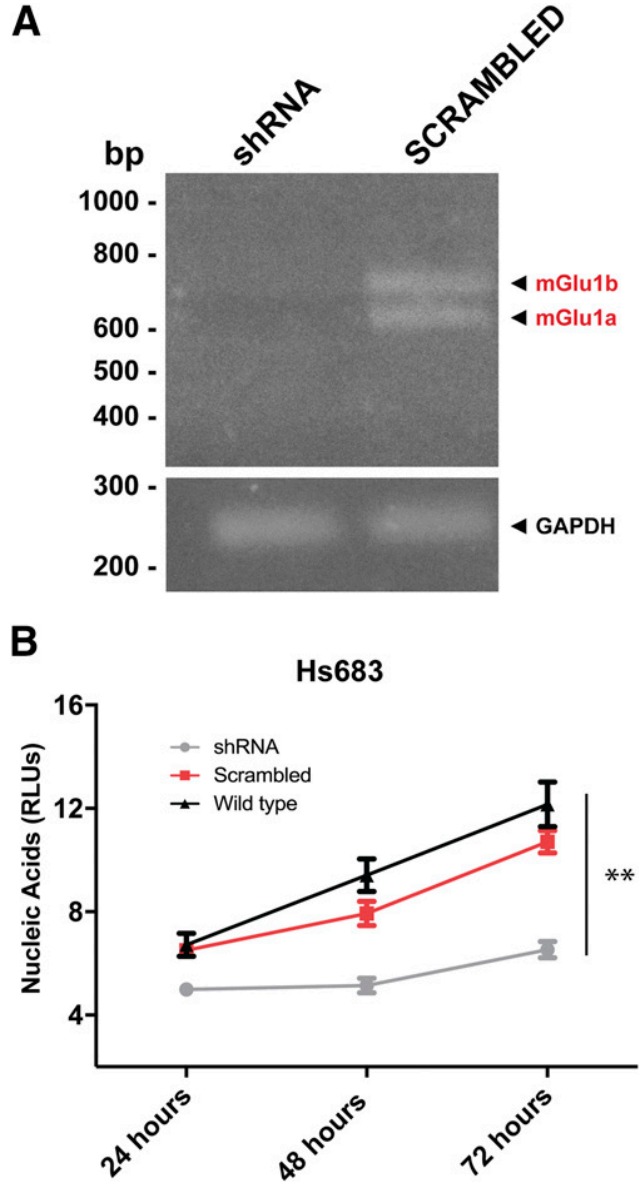

Fig. 5. GRM1 gene silencing with shRNA significantly reduced glioma cell proliferation. (A) Two-percent agarose gel containing PCR products from Hs683 glioma cells transfected with a scrambled shRNA control plasmid or four different mGluR1-targeted shRNA plasmids. GAPDH and mGluR1 products were generated in separate reactions that included equivalent volumes of the same aliquot of cDNA. Photographs were cropped to promote clarity. (B) Hs683 cells were transfected with the shRNA plasmids, scrambled shRNA control, or with transfection agent alone (wild type). Nucleic acid content was measured using the CyQUANT cell proliferation kit 24,48 and 72 hours after the transfected cells were plated on 96-well plates. Relative light units (RLUs) represent measurements of emitted fluorescence by CyQUANT dye. Each data point represents the mean of three independent experiments $(n)$ ( \pm S.E.M.), each with three to five replicates. At 72 hours, a one-way ANOVA with Tukey's Multiple Comparisons Test was used to measure the differences between groups $(* * P<0.01$, comparing wild type and control scrambled shRNA to mGluR1 shRNA).

antagonist JNJ was added to the semisolid media, it inhibited the ability of Hs683 to form colonies and decreased colony size in a dose-dependent manner. Compared with control wells, a trend toward decreased average colony size $\left[20 \mu \mathrm{m}^{2}( \pm 2)\right]$ could be seen with $30 \mu \mathrm{M} \mathrm{JNJ}(P=0.10)$ before a decrease in colony number was observed. A significant difference in both colony number and size was seen when wells treated with $100 \mu \mathrm{M}$ JNJ were compared with control, with an average colony number of $63( \pm 13)$ per well and colony size of $12 \mu \mathrm{m}^{2}( \pm 2$ ) (Fig. 6). Furthermore, an average of $4( \pm 1)$ colonies were detected when Hs683 was cultured in the presence of $300 \mu \mathrm{M}$ JNJ, indicating a conversion to an "extreme" anchorage-dependent growth phenotype. These results suggest noncompetitive antagonism of mGluR1 reduces the tumorigenic and metastatic potential of these glioma cells and predicts that it might be useful to decrease the growth of glioma in an in vivo model.

\section{Discussion}

A variety of cancerous cells release glutamate, including melanoma (Namkoong et al., 2007), breast carcinoma (Seidlitz et al., 2009; Ungard et al., 2014), prostate carcinoma (Seidlitz et al., 2009), and glioma (Ye and Sontheimer, 1999; Takano et al., 2001; Lyons et al., 2007). It has been widely hypothesized that this released glutamate activates glutamatergic receptors expressed on tumor cells in an autocrine and/or paracrine fashion to stimulate proliferation, migration, and survival. Consistent with this hypothesis, all glioma cell lines tested in this study released significant concentrations of glutamate and glutamate dose dependently promoted glioma cell viability (Fig. 1).

Using RT-PCR, mGluR1 splice variant transcripts 1a and $1 \mathrm{~b}$ were detected in all glioma cell lines tested (Fig. 2), validating previous reports of mGluR1 mRNA expression in glioma (Parsons et al., 2008; Stepulak et al., 2009; Brocke et al., 2010) consistent with a study of mGluR1 mRNA expression in melanoma (DiRaddo et al., 2013). Four additional splice variants for mGluR1 have been described (DiRaddo et al., 2013). Assuming one, or more, of other the isoforms of mGluR1 are expressed, it would be important to understand which splice variants increased glioma proliferation. It will also be important to obtain a mGluR1 antibody with adequate specificity to confirm mGluR1 protein expression.

It is well established that glutamate activation of mGluR1 induces a $\mathrm{G} \alpha_{\mathrm{q}}$ protein-mediated signaling cascade that activates phospholipase $\mathrm{C}$, stimulating PI hydrolysis and activating protein kinase C. Reported downstream effects include increased intracellular calcium, facilitation of ionotropic receptor currents (Ferraguti et al., 2008), and transient ERK phosphorylation (Emery et al., 2010, 2012). On the basis of this characterization of mGluR1 signaling, receptor activity is often stimulated with agonists known to stimulate $\mathrm{G} \alpha_{\mathrm{q}}$ signaling and measured using $\mathrm{G} \alpha_{\mathrm{q}}$-signaling pathway outputs such as intracellular calcium concentration and PI hydrolysis (Gelb et al., 2015a). However, our laboratory has reported a mechanism by which glutamate-stimulated mGluR1 mediates cell survival that would not be captured by $\mathrm{G} \alpha_{\mathrm{q}}$-signaling outputs (Gelb et al., 2015a). This mechanism involves a $\mathrm{G} \alpha_{\mathrm{q}^{-}}$ independent, $\beta$-arrestin-dependent signaling cascade that induces sustained ERK phosphorylation and improved cellular viability (Emery et al., 2010). Furthermore, our laboratory has observed evidence of ligand bias at mGluR1 expressed in CHO cells, melanoma cells, and in cerebellar granule neurons (Emery et al., 2012; Gelb et al., 2015a; Hathaway et al., 2015). In these models, unbiased ligands, such as glutamate and aspartate, activate either the $\mathrm{G} \alpha_{\mathrm{q}}$ pathway or the $\beta$-arrestindependent pathway and biased ligands such as quisqualate and DHPG only activate the $\mathrm{G} \alpha_{\mathrm{q}}$ pathway (Emery et al., 2012; Gelb et al., 2015a; Hathaway et al., 2015). We observed a similar pattern in glioma cell lines (Fig. 3A; Supplemental Fig. 4) consistent with the hypothesis that mGluR1 demonstrates ligand bias across several cellular models.

In this study, we confirmed that glioma cells release high concentrations of glutamate into the surrounding culture media (Fig. 1B). This prolonged cellular exposure to glutamate 
A
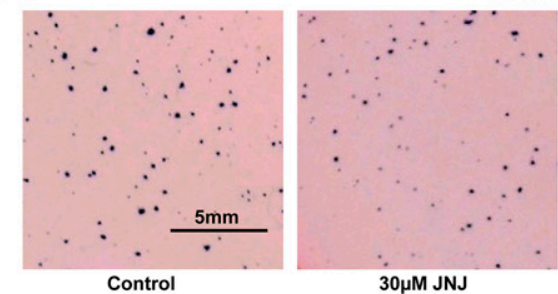

$30 \mu \mathrm{M}$ JNJ

$100 \mu \mathrm{M}$ JNJ

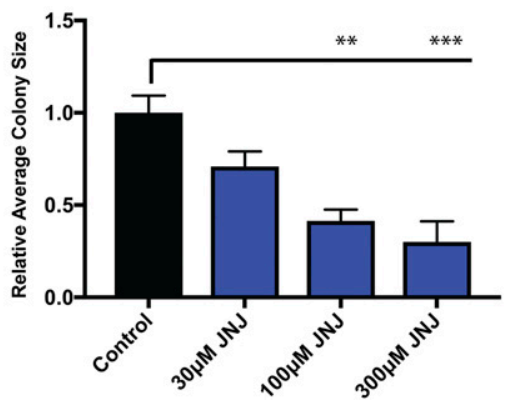

Fig. 6. The noncompetitive mGluR1 selective antagonist JNJ16259685 dose dependently inhibits anchorage-independent growth of Hs683 glioma cells. (A) Representative photographs of Hs683 colonies grown in soft agar for 21 days and then stained overnight with nitro blue tetrazolium chloride. (B) Quantitative analysis of colony formation including the entire well area using Image J. Each bar represents the mean of three $(100 \mu \mathrm{M})$ or four independent experiments (control, 30, $300 \mu \mathrm{M}$ JNJ) measured in duplicate and normalized to the grand mean of each experiment for analysis, and then normalized to the mean of the control group for presentation. Error bars represent the S.E.M. of the independent experiments. One-way ANOVA with Dunnett's Multiple Comparisons Test was used to measure the differences between groups (** $P<0.01 ; * * * P<0.001$ comparing relative colony number or average colony size to the mean of the control group). would probably influence mGluR1 signaling by stimulating homologous receptor desensitization, a process that includes $\beta$-arrestin- and dynamin-dependent receptor internalization (Dhami and Ferguson, 2006; Ferraguti et al., 2008). Theoretically, internalized mGluR1 would not be available at the cell surface to signal through the $\mathrm{G} \alpha_{\mathrm{q}}$ signaling cascade but could signal through the $\beta$-arrestin-dependent pathway, ultimately promoting glioma cell viability. Several studies of mGluR1 desensitization and internalization in heterologous models support this hypothesis (Doherty et al., 1999; Sallese et al., 2000; Mundell et al., 2001; Dhami and Ferguson, 2006; Ferraguti et al., 2008).

To determine if glutamate-stimulated viability was dependent on receptor internalization, we used the dynamin inhibitor dynasore. Dynamin is required for endocytosis of clathrin-coated pits containing mGluR $1 / \beta$-arrestin complexes, an event preceding $\beta$-arrestin-dependent signaling (Macia et al., 2006; Dhami and Ferguson, 2006; Ferraguti et al., 2008). We found that dynasore dose dependently blocked the positive effect of glutamate on glioma cell line viability (Fig. 3B). Although off target effects of dynasore have been reported, including disruptive effects in the regulation of intracellular cholesterol and lipid raft structure (Preta et al., 2015), we found no change in viability when increasing concentrations of dynasore were added to dialyzed media (with GPT added to remove secreted glutamate). This suggests that the observed effect was specifically associated with blockade of glutamate-stimulated effects. With these results as a basis, it is probable that receptor internalization is required for glutamate to promote glioma viability, further supporting our hypothesis that this effect may be $\beta$-arrestindependent.

In this study, the selective mGluR1 noncompetitive antagonists JNJ16259685 (JNJ) and CPCCOEt dose dependently reduced glutamate-stimulated glioma cell viability (Fig. 4) with values consistent with the reported $\mathrm{IC}_{50}$ for inhibition of viability in mGluR1 positive melanoma cell lines (Gelb et al., $2015 b$ ) and in cerebellar granule neurons (Hathaway et al.,
2015). The $\mathrm{IC}_{50}$ values for viability are significantly higher than those reported for inhibition of $\mathrm{G} \alpha_{\mathrm{q}}$ mGluR1 signaling [1.2-19 nM for JNJ (Knöpfel, 2007) and 6.5 $\mu \mathrm{M}$ for CPCCOEt (Litschig et al., 1999)]. It has been suggested that the difference in $\mathrm{IC}_{50}$ values for antagonists inhibiting mGluR1 signaling via $\mathrm{G} \alpha_{\mathrm{q}}$ versus $\beta$-arrestin may reflect "biased antagonism," by which the noncompetitive antagonists have an increased potency for receptor conformations that inhibit $\mathrm{G} \alpha_{\mathrm{q}}$ signaling compared with receptor conformations that inhibit glutamate-dependent viability effects (Hathaway et al., 2015). Another possibility exists in glioma, where sustained elevations in local glutamate concentration at mGluR1 would be expected to induce $\beta$-arrestin-dependent receptor internalization. In this context, it is probable that higher concentrations of antagonist are required to overcome the cell membrane barriers to reach internalized mGluR1.

There is substantial evidence that both ionotropic and other metabotropic glutamate receptors promote glioma proliferation, migration, and survival (Takano et al., 2001; Ishiuchi et al., 2002, 2007; D'Onofrio et al., 2003; Arcella et al., 2005; Lyons et al., 2007; Nicoletti et al., 2007; Ciceroni et al., 2013; Zhou et al., 2014; Pereira et al., 2017). Therefore, it is possible that the higher doses of noncompetitive antagonists required to affect viability may reflect activity at those receptors. However, when shRNA targeted against GRM1 was transfected into Hs683 cells, we measured significantly reduced glioma cell proliferation (Fig. 5B) compared with scrambled shRNA controls. This validates our pharmacological data and suggests that mGluR1 is specifically involved in glioma proliferation.

Anchorage-independent growth is a widely used, highly reliable test of malignant transformation (Mori et al., 2009; Borowicz et al., 2014). The assay measures cellular proliferation in the absence of extracellular matrix binding, predicting an in vivo capability to form metastatic tumors (Freedman and Shin, 1974; Mori et al., 2009). When we cultured Hs683 cells in soft agar, the cells exhibited significant anchorageindependent growth (Fig. 6). However, as increasing 
concentrations of JNJ were added to the soft agar, both colony size and number were reduced, indicating a conversion to an anchorage-dependent phenotype. A trend toward decreased colony size was observed at $30 \mu \mathrm{M}$ JNJ, and significant differences in both colony size and number were measured at $100 \mu \mathrm{M}$, concentrations that had minimal effects on cell viability (compare Figs. 4 and 6). Therefore, the effects observed at $100 \mu \mathrm{M}$ JNJ in soft agar probably reflect an inhibition of anchorage-dependent growth, rather than a reduction in proliferation or viability in general. These results suggest that noncompetitive antagonism of mGluR1 may decrease the tumorigenic and metastatic potential of glioma cells in vivo.

A common finding in cancer genetics is "selective reexpression" (Coggin and Anderson, 1974) of genes that regulate early growth and development (Ligon et al., 2017). mGluR1 has been associated with neurogenesis, including the enhancement of neural progenitor cell proliferation (Baskys et al., 2005; Castiglione et al., 2008; Friedman et al., 2016). Furthermore, mGluR1 appears to regulate oxidative stress in immature oligodendrocytes, with expression levels dropping dramatically with development (Deng et al., 2004; Loane et al., 2012). In the present study, we detected mGluR1 mRNA in the Hs683 glioma cell line, an oligodendroglioma with a GBM phenotype (Le Mercier et al., 2009; Bruyère et al., 2011). We also detected mGluR1 mRNA expression in cell lines classified as high-grade astrocytoma or GBM (Fig. 2; U87, A172, and U118). The consistent expression of mGluR1 mRNA in high-grade astrocytoma (Parsons et al., 2008; Stepulak et al., 2009; Brocke et al., 2010) is somewhat surprising, because mGluR1 has not been detected in normal astrocytes and has only been found in spinal cord astrocytes in pathologic contexts such as traumatic injury or ALS (Agrawal et al., 1998; Aronica et al., 2001; D'Antoni et al., 2008). These findings parallel what has been seen in melanoma, where mGluR1 is not detected in melanocytes but is detected in the malignant phenotype melanoma (Shin et al., 2008; Wangari-Talbot et al., 2012). Furthermore, there is substantial evidence from our laboratory (Gelb et al., 2014, 2015a,b) and from others to suggest that mGluR1 acts as a proto-oncogene when aberrantly expressed in melanoma (Marín et al., 2006; Namkoong et al., 2007; Shin et al., 2008) and breast cancer (Speyer et al., 2012; Banda et al., 2014). Among the most convincing evidence, is the report that mGluR1 cDNA transfection into melanocytes transforms the cells to a melanoma phenotype that can be subsequently reversed with knockdown of the receptor (Shin et al., 2008). In the present study, we focused exclusively on glioma cell lines to provide evidence that mGluR1 may play a similar role in yet another form of malignancy. We demonstrate that glioma cell viability is dependent on glutamate (Fig. 1), and that blockade of mGluR1 signaling with selective noncompetitive antagonists (Fig. 4) and with genetic silencing (Fig. 5) significantly reduces glutamate-stimulated glioma cell viability and proliferation. In addition, we demonstrate that the noncompetitive selective mGluR1 antagonist JNJ16259685 can convert Hs683 cells grown in soft agar from an anchorage-independent phenotype to an anchorage-dependent phenotype, predicting that Hs683 cells treated with this antagonist will exhibit fewer metastatic and tumorigenic characteristics in vivo (Fig. 6). Taken together, these results strongly suggest that mGluR 1 may act as a proto-oncogene in glioma by promoting dysregulated proliferation and survival of glioma cells in a manner similar to the role of mGluR 1 in melanoma. This effect may be the result of "selective re-expression" of GRM1, the mGluR1 gene, which in normal developmental physiology, drives the proliferation of neural progenitor cells (Baskys et al., 2005; Castiglione et al., 2008; Friedman et al., 2016) and promotes the survival of immature oligodendrocytes (Deng et al., 2004). Thus, inhibition of $\mathrm{mGluR} 1$ signaling may offer an alternative strategy for treating glioma. Future testing in translational models will be important to determine if mGluR1 signaling can provide an opportunity to diversify GBM treatment in an effort to combat treatment resistance and improve the prognosis of this devastating disease. In addition, on the basis of these findings in glioma, and those in melanoma and breast cancer, a comprehensive screen of mGluR1 involvement across other malignancies is warranted.

\section{Acknowledgments}

We thank Robert Yasuda (Georgetown University) and Tara Gelb (National Institutes of Health) for making suggestions that improved the experimental design and quality of this manuscript.

\section{Authorship Contributions}

Participated in research design: Dalley, Wroblewska, Wolfe, Wroblewski.

Conducted experiments: Dalley, Wroblewska.

Performed data analysis: Dalley, Wroblewska, Wolfe, Wroblewski. Wrote or contributed to the writing of the manuscript: Dalley, Wroblewska, Wolfe.

\section{References}

Agrawal SK, Theriault E, and Fehlings MG (1998) Role of group I metabotropic glutamate receptors in traumatic spinal cord white matter injury. $J$ Neurotrauma 15:929-941.

Arcella A, Carpinelli G, Battaglia G, D’Onofrio M, Santoro F, Ngomba RT, Bruno V, Casolini P, Giangaspero F, and Nicoletti F (2005) Pharmacological blockade of group II metabotropic glutamate receptors reduces the growth of glioma cells in vivo. Neuro Oncol 7:236-245.

Aronica E, Catania MV, Geurts J, Yankaya B, and Troost D (2001) Immunohistochemical localization of group I and II metabotropic glutamate receptors in control and amyotrophic lateral sclerosis human spinal cord: upregulation in reactive astrocytes. Neuroscience 105:509-520.

Aronica E, Gorter JA, Ijlst-Keizers H, Rozemuller AJ, Yankaya B, Leenstra S, and Troost D (2003) Expression and functional role of mGluR3 and mGluR5 in human astrocytes and glioma cells: opposite regulation of glutamate transporter proteins. Eur J Neurosci 17:2106-2118.

Banda M, Speyer CL, Semma SN, Osuala KO, Kounalakis N, Torres Torres KE, Barnard NJ, Kim HJ, Sloane BF, Miller FR, et al. (2014) Metabotropic glutamate receptor-1 contributes to progression in triple negative breast cancer. PLoS One 9: e81126.

Baskys A, Bayazitov I, Fang L, Blaabjerg M, Poulsen FR, and Zimmer J (2005) Group I metabotropic glutamate receptors reduce excitotoxic injury and may facilitate neurogenesis. Neuropharmacology 49 (Suppl 1):146-156.

Borowicz S, Van Scoyk M, Avasarala S, Rathinam MKK, Tauler J, Bikkavilli RK, and Winn RA (2014) The soft agar colony formation assay. J Vis Exp 92:51998.

Brocke KS, Staufner C, Luksch H, Geiger KD, Stepulak A, Marzahn J, Schackert G, Temme A, and Ikonomidou C (2010) Glutamate receptors in pediatric tumors of the central nervous system. Cancer Biol Ther 9:455-468.

Bruyère C, Abeloos L, Lamoral-Theys D, Senetta R, Mathieu V, Le Mercier M, Kast RE, Cassoni P, Vandenbussche G, Kiss R, et al. (2011) Temozolomide modifies caveolin-1 expression in experimental malignant gliomas in vitro and in vivo. Transl Oncol 4:92-100.

Buckingham SC, Campbell SL, Haas BR, Montana V, Robel S, Ogunrinu T, and Sontheimer H (2011) Glutamate release by primary brain tumors induces epileptic activity. Nat Med 17:1269-1274

Camby I, Bruyneel E, Geurts A, Decaestecker C, Sweep F, Brotchi J, Mareel M, Kiss $R$, and Salmon I (2000) Do human oligodendroglial and astroglial tumors derive from mature oligodendrocytes and astrocytes, or from precursor glial cells? Brain Pathol 10:569.

Castiglione M, Calafiore M, Costa L, Sortino MA, Nicoletti F, and Copani A (2008) Group I metabotropic glutamate receptors control proliferation, survival and differentiation of cultured neural progenitor cells isolated from the subventricular zone of adult mice. Neuropharmacology 55:560-567.

Ciceroni C, Bonelli M, Mastrantoni E, Niccolini C, Laurenza M, Larocca LM, Pallini R, Traficante A, Spinsanti P, Ricci-Vitiani L, et al. (2013) Type-3 metabotropic glutamate receptors regulate chemoresistance in glioma stem cells, and their levels are inversely related to survival in patients with malignant gliomas. Cell Death Differ 20:396-407. 
Coggin JH Jr and Anderson NG (1974) Cancer, differentiation and embryonic antigens: some central problems. Adv Cancer Res 19:105-165.

D'Antoni S, Berretta A, Bonaccorso CM, Bruno V, Aronica E, Nicoletti F, and Catania MV (2008) Metabotropic glutamate receptors in glial cells. Neurochem Res 33: $2436-2443$.

de Groot J and Sontheimer H (2011) Glutamate and the biology of gliomas. Glia 59: $1181-1189$

Deng W, Wang H, Rosenberg PA, Volpe JJ, and Jensen FE (2004) Role of metabotropic glutamate receptors in oligodendrocyte excitotoxicity and oxidative stress Proc Natl Acad Sci USA 101:7751-7756.

Dhami GK and Ferguson SS (2006) Regulation of metabotropic glutamate receptor signaling, desensitization and endocytosis. Pharmacol Ther 111:260-271.

DiRaddo JO, Pshenichkin S, Gelb T, and Wroblewski JT (2013) Two newly identified exons in human GRM1 express a novel splice variant of metabotropic glutamate 1 receptor. Gene 519:367-373.

Doherty AJ, Coutinho V, Collingridge GL, and Henley JM (1999) Rapid internalization and surface expression of a functional, fluorescently tagged G-protein-coupled glutamate receptor. Biochem $J$ 341:415-422.

D'Onofrio M, Arcella A, Bruno V, Ngomba RT, Battaglia G, Lombari V, Ragona G, Calogero A, and Nicoletti F (2003) Pharmacological blockade of mGlu2/3 metabotropic glutamate receptors reduces cell proliferation in cultured human glioma cells. J Neurochem 84:1288-1295.

Duffau H (2013) Diffuse Low-Grade Gliomas in Adults, Springer, London.

Dzubay JA and Jahr CE (1999) The concentration of synaptically released glutamate outside of the climbing fiber-Purkinje cell synaptic cleft. $J$ Neurosci 19:5265-5274.

Emery AC, DiRaddo JO, Miller E, Hathaway HA, Pshenichkin S, Takoudjou GR, Grajkowska E, Yasuda RP, Wolfe BB, and Wroblewski JT (2012) Ligand bias at metabotropic glutamate 1a receptors: molecular determinants that distinguish $\beta$-arrestin-mediated from G protein-mediated signaling. Mol Pharmacol 82: 291-301.

Emery AC, Pshenichkin S, Takoudjou GR, Grajkowska E, Wolfe BB, and Wroblewski JT (2010) The protective signaling of metabotropic glutamate receptor 1 is mediated by sustained, beta-arrestin-1-dependent ERK phosphorylation. J Biol Chem 285:26041-26048.

Ferraguti F, Crepaldi L, and Nicoletti F (2008) Metabotropic glutamate 1 receptor: current concepts and perspectives. Pharmacol Rev 60:536-581.

Freedman VH and Shin SI (1974) Cellular tumorigenicity in nude mice: correlation with cell growth in semi-solid medium. Cell 3:355-359.

Friedman LK, Sharma A, Corcia M, Webster T, Qazi L, Simsovits D, Khalil Y, Hu S, Kantrowitz M, and Hong H (2016) Selective inhibition of metabotropic glutamate type 1 alpha receptor $(m G l u R 1 \alpha)$ reduces cell proliferation and migration following status epilepticus in early development. Int $J$ Dev Neurosci 54:6-21.

Gasparini F, Lingenhöhl K, Stoehr N, Flor PJ, Heinrich M, Vranesic I, Biollaz M, Allgeier H, Heckendorn R, Urwyler S, et al. (1999) 2-Methyl-6-(phenylethynyl)pyridine (MPEP), a potent, selective and systemically active mGlu5 receptor antagonist. Neuropharmacology 38:1493-1503.

Gelb T, Hathaway HA, and Wroblewski JT (2014) Triple threat treatment: exploiting the dependence receptor properties of metabotropic glutamate receptor 1 against melanoma. Mol Cell Oncol 1:e969163.

Gelb T, Pshenichkin S, Hathaway HA, Grajkowska E, Dalley CB, Wolfe BB, and Wroblewski JT (2015a) Atypical signaling of metabotropic glutamate receptor 1 in human melanoma cells. Biochem Pharmacol 98:182-189.

Gelb T, Pshenichkin S, Rodriguez OC, Hathaway HA, Grajkowska E, DiRaddo JO, Wroblewska B, Yasuda RP, Albanese C, Wolfe BB, et al. (2015b) Metabotropic glutamate receptor 1 acts as a dependence receptor creating a requirement for glutamate to sustain the viability and growth of human melanomas. Oncogene $\mathbf{3 4}$ 2711-2720.

Giard DJ, Aaronson SA, Todaro GJ, Arnstein P, Kersey JH, Dosik H, and Parks WP (1973) In vitro cultivation of human tumors: establishment of cell lines derived from a series of solid tumors. J Natl Cancer Inst 51:1417-1423.

Gilbert MR, Dignam JJ, Armstrong TS, Wefel JS, Blumenthal DT, Vogelbaum MA Colman H, Chakravarti A, Pugh S, Won M, et al. (2014) A randomized trial of bevacizumab for newly diagnosed glioblastoma. N Engl J Med 370:699-708.

Hathaway HA, Pshenichkin S, Grajkowska E, Gelb T, Emery AC, Wolfe BB, and Wroblewski JT (2015) Pharmacological characterization of mGlu1 receptors in cerebellar granule cells reveals biased agonism. Neuropharmacology 93:199-208.

Ishiuchi S, Tsuzuki K, Yoshida Y, Yamada N, Hagimura N, Okado H, Miwa A, Kurihara H, Nakazato Y, Tamura M, et al. (2002) Blockage of $\mathrm{Ca}(2+)$-permeable AMPA receptors suppresses migration and induces apoptosis in human glioblastoma cells. Nat Med 8:971-978.

Ishiuchi S, Yoshida Y, Sugawara K, Aihara M, Ohtani T, Watanabe T, Saito N, Tsuzuki K, Okado H, Miwa A, et al. (2007) Ca2+-permeable AMPA receptors regulate growth of human glioblastoma via Akt activation. $J$ Neurosci 27: $7987-8001$

Jo HY, Kim Y, Park HW, Moon HE, Bae S, Kim J, Kim DG, and Paek SH (2015) The unreliability of MTT assay in the cytotoxic test of primary cultured glioblastoma cells. Exp Neurobiol 24:235-245.

Knöpfel T (2007) Two new non-competitive mGlu1 receptor antagonists are potent tools to unravel functions of this mGlu receptor subtype. $\mathrm{Br} J$ Pharmacol 151:723-724.

Lacroix M, Abi-Said D, Fourney DR, Gokaslan ZL, Shi W, DeMonte F, Lang FF, McCutcheon IE, Hassenbusch SJ, Holland E, et al. (2001) A multivariate analysis of 416 patients with glioblastoma multiforme: prognosis, extent of resection, and survival. J Neurosurg 95:190-198.

Lavreysen H, Wouters R, Bischoff F, Nóbrega Pereira S, Langlois X, Blokland S, Somers M, Dillen L, and Lesage AS (2004) JNJ16259685, a highly potent, selective and systemically active mGlu1 receptor antagonist. Neuropharmacology 47:961-972.

Le Mercier M, Fortin S, Mathieu V, Roland I, Spiegl-Kreinecker S, Haibe-Kains B, Bontempi G, Decaestecker C, Berger W, Lefranc F, et al. (2009) Galectin 1 proangiogenic and promigratory effects in the Hs683 oligodendroglioma model are partly mediated through the control of BEX2 expression. Neoplasia 11:485-496.
Ligon KL, Wilkinson K, and Stiles CD (2017) Pathology and molecular pathology of brain cancer, in Pathology and Epidemiology of Cancer (Loda M, Mucci LA, Mittelstadt ML, Hemelrijck MV, and Cotter MB eds) pp 291-311, Springer International Publishing, Basel, Switzerland.

Litschig S, Gasparini F, Rueegg D, Stoehr N, Flor PJ, Vranesic I, Prézeau L, Pin JP Thomsen C, and Kuhn R (1999) CPCCOEt, a noncompetitive metabotropic glutamate receptor 1 antagonist, inhibits receptor signaling without affecting glutamate binding. Mol Pharmacol 55:453-461.

Loane DJ, Stoica BA, and Faden AI (2012) Metabotropic glutamate receptormediated signaling in neuroglia. Wiley Interdiscip Rev Membr Transp Signal 1 136-150.

Louis DN, Ohgaki H, Wiestler OD, Cavenee WK, Burger PC, Jouvet A, Scheithauer $\mathrm{BW}$, and Kleihues P (2007) The 2007 WHO classification of tumours of the central nervous system. Acta Neuropathol 114:97-109.

Lyons SA, Chung WJ, Weaver AK, Ogunrinu T, and Sontheimer H (2007) Autocrine glutamate signaling promotes glioma cell invasion. Cancer Res 67:9463-9471.

Macia E, Ehrlich M, Massol R, Boucrot E, Brunner C, and Kirchhausen T (2006) Dynasore, a cell-permeable inhibitor of dynamin. Dev Cell 10:839-850.

Maglott A, Bartik P, Cosgun S, Klotz P, Rondé P, Fuhrmann G, Takeda K, Martin S, and Dontenwill M (2006) The small alpha5beta1 integrin antagonist, SJ749, reduces proliferation and clonogenicity of human astrocytoma cells. Cancer Res $\mathbf{6 6}$ 6002-6007.

Malkki H (2016) Trial watch: glioblastoma vaccine therapy disappointment in phase III trial. Nat Rev Neurol 12:190.

Marín YE, Namkoong J, Cohen-Solal K, Shin SS, Martino JJ, Oka M, and Chen S (2006) Stimulation of oncogenic metabotropic glutamate receptor 1 in melanoma cells activates ERK1/2 via PKCepsilon. Cell Signal 18:1279-1286.

Mori S, Chang JT, Andrechek ER, Matsumura N, Baba T, Yao G, Kim JW, Gatza M, Murphy S, and Nevins JR (2009) Anchorage-independent cell growth signature identifies tumors with metastatic potential. Oncogene 28:2796-2805.

Mundell SJ, Matharu AL, Pula G, Roberts PJ, and Kelly E (2001) Agonist-induced internalization of the metabotropic glutamate receptor $1 \mathrm{a}$ is arrestin- and dynamin-dependent. $J$ Neurochem 78:546-551.

Namkoong J, Shin SS, Lee HJ, Marín YE, Wall BA, Goydos JS, and Chen S (2007) Metabotropic glutamate receptor 1 and glutamate signaling in human melanoma. Cancer Res 67:2298-2305.

Nicoletti F, Arcella A, Iacovelli L, Battaglia G, Giangaspero F, and Melchiorri D (2007) Metabotropic glutamate receptors: new targets for the control of tumor growth? Trends Pharmacol Sci 28:206-213.

Ostrom QT, Bauchet L, Davis FG, Deltour I, Fisher JL, Langer CE, Pekmezci M, Schwartzbaum JA, Turner MC, Walsh KM, et al. (2014) The epidemiology of glioma in adults: a "state of the science" review. Neuro Oncol 16:896-913.

Parsons DW, Jones S, Zhang X, Lin JC, Leary RJ, Angenendt P, Mankoo P, Carter H, Siu IM, Gallia GL, et al. (2008) An integrated genomic analysis of human glioblastoma multiforme. Science 321:1807-1812.

Pereira MSL, Klamt F, Thomé CC, Worm PV, and de Oliveira DL (2017) Metabotropic glutamate receptors as a new therapeutic target for malignant gliomas. Oncotarget 8:22279-22298.

Preta G, Cronin JG, and Sheldon IM (2015) Dynasore - not just a dynamin inhibitor. Cell Commun Signal 13:24.

Robert SM and Sontheimer H (2014) Glutamate transporters in the biology of malignant gliomas. Cell Mol Life Sci 71:1839-1854.

Roth P and Weller M (2014) Challenges to targeting epidermal growth factor receptor in glioblastoma: escape mechanisms and combinatorial treatment strategies. Neuro Oncol 16 (suppl 8):viii14-viii19.

Rzeski W, Turski L, and Ikonomidou C (2001) Glutamate antagonists limit tumor growth. Proc Natl Acad Sci USA 98:6372-6377.

Sallese M, Salvatore L, D'Urbano E, Sala G, Storto M, Launey T, Nicoletti F, Knöpfel T, and De Blasi A (2000) The G-protein-coupled receptor kinase GRK4 mediates homologous desensitization of metabotropic glutamate receptor 1 . FASEB $J \mathbf{1 4}$ $2569-2580$

Schwartzbaum JA, Fisher JL, Aldape KD, and Wrensch M (2006) Epidemiology and molecular pathology of glioma. Nat Clin Pract Neurol 2:494-503, quiz 1, 516.

Seidlitz EP, Sharma MK, Saikali Z, Ghert M, and Singh G (2009) Cancer cell lines release glutamate into the extracellular environment. Clin Exp Metastasis 26: 781-787.

Shin SS, Namkoong J, Wall BA, Gleason R, Lee HJ, and Chen S (2008) Oncogenic activities of metabotropic glutamate receptor 1 (Grm1) in melanocyte transformation. Pigment Cell Melanoma Res 21:368-378.

Soda Y, Myskiw C, Rommel A, and Verma IM (2013) Mechanisms of neovascularization and resistance to anti-angiogenic therapies in glioblastoma multiforme. J Mol Med (Berl) 91:439-448.

Speyer CL, Smith JS, Banda M, DeVries JA, Mekani T, and Gorski DH (2012) Metabotropic glutamate receptor-1: a potential therapeutic target for the treatment of breast cancer. Breast Cancer Res Treat 132:565-573.

Stepanenko AA and Dmitrenko VV (2015) Pitfalls of the MTT assay: direct and offtarget effects of inhibitors can result in over/underestimation of cell viability. Gene 574:193-203.

Stepulak A, Luksch H, Gebhardt C, Uckermann O, Marzahn J, Sifringer M, Rzeski W, Staufner C, Brocke KS, Turski L, et al. (2009) Expression of glutamate receptor subunits in human cancers. Histochem Cell Biol 132:435-445.

Stupp R, Hegi ME, Mason WP, van den Bent MJ, Taphoorn MJ, Janzer RC, Ludwin SK, Allgeier A, Fisher B, Belanger K, et al.; European Organisation for Research and Treatment of Cancer Brain Tumour and Radiation Oncology Groups; National Cancer Institute of Canada Clinical Trials Group (2009) Effects of radiotherapy with concomitant and adjuvant temozolomide versus radiotherapy alone on survival in glioblastoma in a randomised phase III study: 5-year analysis of the EORTC-NCIC trial. Lancet Oncol 10:459-466.

Takano T, Lin JH, Arcuino G, Gao Q, Yang J, and Nedergaard M (2001) Glutamate release promotes growth of malignant gliomas. Nat Med 7:1010-1015. 
Thomas AG, Sattler R, Tendyke K, Loiacono KA, Hansen H, Sahni V, Hashizume Y, Rojas C, and Slusher BS (2015) High-throughput assay development for cystine-glutamate antiporter (xc-) highlights faster cystine uptake than glutamate release in glioma cells. PLoS One 10 e0127785.

Ungard RG, Seidlitz EP, and Singh G (2014) Inhibition of breast cancer-cell glutamate release with sulfasalazine limits cancer-induced bone pain. Pain 155:28-36.

Wangari-Talbot J, Wall BA, Goydos JS, and Chen S (2012) Functional effects of GRM1 suppression in human melanoma cells. Mol Cancer Res 10 1440-1450.

Willard SS and Koochekpour S (2013) Glutamate signaling in benign and malignant disorders: current status, future perspectives, and therapeutic implications. Int $J$ Biol Sci 9:728-742.
Ye ZC and Sontheimer H (1999) Glioma cells release excitotoxic concentrations of glutamate. Cancer Res 59:4383-4391.

Zhou K, Song Y, Zhou W, Zhang C, Shu H, Yang H, and Wang B (2014) mGlus receptor blockade inhibits proliferation and promotes astrocytic phenotype in glioma stem cells. Cell Biol Int 38:426-434.

Zinn PO, Colen RR, Kasper EM, and Burkhardt JK (2013) Extent of resection and radiotherapy in GBM: a 1973 to 2007 surveillance, epidemiology and end results analysis of 21,783 patients. Int J Oncol 42:929-934.

Address correspondence to: Dr. Carrie Bowman Dalley, Georgetown University, Rm 430, St. Mary's Hall, 3700 Reservoir Rd. NW, Washington, DC 20057. E-mail: ccb23@georgetown.edu 